\title{
Assessing Daylight Performance of Single vs. Double Skin Façade in Educational Buildings: A Comparative Analysis of Two Case Studies
}

\author{
Islam Ghonimi ${ }^{1}$ \\ ${ }^{1}$ Architecture Department, Shoubra Faculty of engineering, Benha University, Egypt \\ Correspondence: Islam Ghonimi, 11B Tower, Nasr City Towers, Nasr City, Cairo, Egypt. Tel: 2-012-2199-6789. \\ E-mail: islamghonimi@yahoo.com; Islam.ghonimi@feng.bu.edu.eg
}

Received: March 9, 2017

doi:10.5539/jsd.v10n3p133
Accepted: April 7, $2017 \quad$ Online Published: May 31, 2017

URL: https://doi.org/10.5539/jsd.v10n3p133

\begin{abstract}
The bulk of research on the performance of double skin facade is carried out in moderate climate with concern to ventilation and thermal performance. This research concerns day-light performance of double skin facades in hot arid zones, in Educational Buildings. This investigation adopts an inductive method using comparative analytical approach to convert general intuitions on the daylight performance of a double skin facade, in hot arid areas, into the grounds of understanding its performance based on research.

Based on two case studies of lecture halls; the first with Single Skin Façade (SSF) and the second with Double Skin Façade (DSF); the impact of double skin façade on lighting performance is examined. The Protocol was applied to south facing models under overcast sky conditions to test significant effects of double skin façade on illumance values inside the lecture halls. Simulation results indicate that a double skin facade can achieve high lighting performance with better energy savings than a single skin façade; also the basic characteristics of width and distance of two walls are examined. It was expected that DSF fail to meet the acceptable standard indoor illuminance requirement of 200 to 300 lux. Comparing the single and double skin facade, the area percentage of the lecture hall, which covered with acceptable illumination level of 200 to 300 lux, are found in range of $10 \%$, $50 \%$ respectively. In addition, the area percentage of the lecture hall, which covered with acceptable illumination level of 100 to 300 lux, is found in range of $30 \%, 80 \%$ respectively.
\end{abstract}

Keywords: double skin façade, efficient and sufficient daylight, educational buildings, energy efficiency and visual comfort

\section{Introduction}

The problem addressed by this study is that educational spaces have certain environmental requirements to assure that students can perform mental tasks in appropriate ways. These requirements include natural ventilation, daylight distribution, heat gain, air quality, and humidity; sometimes these requirements contradict with each other (Schneider, M. 2002). For lecture hall to perform best, an efficient ventilation are required that depends on large distributed windows, it worth affects excessive day-light entry and excessive heat gain entry, accordingly poor environmental conditions otherwise we have to minimize windows size to reduce heat gain and control daylight and accordingly minimize required ventilation (Note 1).

Double skin is a concept that can be used to meet lighting problems of in-sufficient daylight or extra glare of daylight. The bulk of research on the performance of double facade is carried out in moderate climates with concern to ventilation and thermal performance. This research concerns day-light performance of double skin facades in educational buildings in hot arid zones. An optimization of this configuration is needed to improve its performance in educational spaces in terms of daylight (Hamza, N., 2007).

\subsection{Research Problem}

Educational buildings are building typology that requires efficient lighting conditions in term of sufficient daylight quantity and efficient daylight quality. Two problems can be traced, the first problem caused by insufficient quantity of natural daylight, that cause high rates of energy consumption due to used artificial lighting alternative. The second problem caused by extra daylight that causes an inefficient unequal distribution of daylight in lecture halls that cause areas that are too dim and other that are too bright accordingly an extra glare of daylight exist, beside a relative increase in solar gain. These two problems forces occupants to fully 
close their shading system and use artificial lighting to avoid direct sunlight and glare and accordingly cause an increase in energy consumption.

\subsection{Research Aim}

This study aims to assess the impact of double skin facades on daylight performance of educational spaces in hot arid zones. It aims to introduce the role of double skin façade in term of quality and quantity that could enhance the role of natural light into educational buildings as a step to achieve applicable sustainability energy guidelines and strategies for management of educational buildings.

\subsection{Research Hypothis}

In educational buildings, lighting comfort and energy consumption are significantly enhanced using double skin façade. This can be overcome by breaking up sunlight either by reflecting it on to the ceiling or by diffusing it through baffles. Double skin façade is tested to overcome such obstacles.

\subsection{Research Methodology}

Inductive method is used; with comparative analysis of daylight performance of two different façade design strategies, a single skin base case is compared against double skin base case, and the result is compared with international codes for educational space lighting. Two case studies of lecture halls are examined; the first with Single Skin Façade (SSF) and the second with Double Skin Façade (DSF) with similar orientation are compared to deduce the impact of double skin façade on daylight performance. A quantitative method using Lux meter was utilized in order to collect and measure data. Golden server software was used to provide data in graphical presentation, in order to be analyzed and compared.

\section{Daylight in Lecture Halls, and the Role of Double Skin Façade}

\subsection{Daylight in Lecture Halls}

Daylight in lecture halls requires two goals to achieve good design; the first is to achieve the optimum required indoor environmental quality of comfort level, good daylight level, and cooling level required for educational spaces to influence health and productivity inside educational spaces. The second is to reduce building energy consumption for heating cooling and electric artificial lighting to cover the shortage or excessive entry of heating and cooling, daylight, and ventilation that influence comfort (Mirrahimi, S. et al. 2013).

Performance, Efficiency and Comfort (PEC) are three core values applied to lighting in educational spaces. To determine the effectiveness of lighting, its impact on the students' performance and teachers learning style (Fontoynont, M. 2004).

Daylight Performance provides the best visual effectiveness. The lighting objective for a lecture hall is to help create the right environment for learning. Tasks are generally carried out on desks and wall mounted whiteboards all need to be seen, therefore good horizontal and vertical lighting is essential to enhance body language and facial expressions of lecturers. Daylight Efficiency aims to minimize using artificial lighting and accordingly reducing energy consumption. It is common for a classroom to have significant amounts of daylight to reduce power demand and conserve energy. Daylight Comfort concerns student's satisfaction increase their concentration. Diffused and will distributed daylight ensures the space has a balanced ambience.

In educational space, day lighting recognized as a useful source of energy savings and visual comforts in buildings. Occupants expect good daylight in their working spaces. The quality and quantity of natural light entering a building depends on both internal and external factors (Danny \&Tsang 2008).

\subsection{Daylight and Double Skin Façade}

Daylight is a visible radiation which is generated by the sun. It can reach in three different ways, direct solar component, externally reflected component, and internally reflected component (Abdulsalam M. etal. 2014). The direct sunlight cause entry of solar heat gain and increases extra entry of sunlight that cause glare, Educational space in order to perform best need to exclude the direct sunlight and depend on internal and external reflected components.

Double skin facade is a double layer of facade separated by an air gap that varies in its minimal depth ranges between centimeters to meters. It creates an envelope that have provides buffer zone for moderating and controlling the relation between indoor and outdoor environmental conditions (Rahmani etal. 2012).

Double Skin Façade can exclude most direct sunlight and introduce reflected light, to control entering daylight and heat gain. Access of continuous homogeneous daylight is important for educational spaces for two reasons, to avoid excessive darkness to avoid excessive glare caused by excessive entry of daylight at certain times of the 
day to face their negative impacts, with reducing consumed energy to achieve required lighting level (Napier, J. 2015).

\subsection{Daylight Guidelines in Educational Building}

Different organizations recommend different lighting levels of illumination for Lecture hall spaces. Two factors are used to insure high performance, efficiency and comfort lighting goals, the first is quantitative measure of daylight intensity and the second is qualitative measure of daylight distribution:

Regarding the intensity factor, natural daylight illumination can vary from 5000 lux in a heavily overcast sky to over 40,000 lux in direct sunlight. These values are significantly greater than what adequate indoor lighting demands. Guidelines for national quality assurance center (NQAC) recommends that the interior lighting level of lecture halls, in order to provide an efficient visual representation for students to best performance of general tasks, should be defined by bottom and top boundaries of $200-300$ lux respectively. In terms of daylight factor, the recommended percentage is $2 \%-5 \%$ (NQAC).

Regarding Quality of daylight distribution, better visual environment recommended range within the occupant' $\mathrm{s}$ field of view, ratios up to 1:10 will be acceptable for student's eye to adapt to day light, (IES North America, 2000). It assures to provide an acceptable argument for high contrast and prevents the false perception of light level inside spaces. It achieves continuous distribution of lighting within range not exceeding 1 to 10 between lower dark and higher glared area to avoid glare (Hopkinson,1966).

\section{Method}

In order to test the significance difference between the impacts of double skin façade versus single skin façade on daylight performance of lecture halls, a case study of two lecture halls are examined, a comparison between their recorded values are presented and compared.

\subsection{Case Study Selection}

Two case studies of lecture halls in two educational building in Benha University are selected; the first is agriculture engineering department - faculty of Agriculture, the second faculty of engineering - Benha University. The two buildings are constructed on the same two main orientations north south. Selected case studies intended to present variables of the study, the first based on single skin façade, and the second based on double skin façade extending as a continuous flow channel over 4 stores from down to top.

Figure (1) explores the difference between the two building envelopments configuration; and the difference in their impacts on interior lighting appearance is explored as in interior view of the hall in Figure (2). The selected case study follows fixed constraints in term of area, height, and orientation. Also measurements follow fixed constraints in term of work plane of $0.8 \mathrm{~m}$ and measurement time of 11 to 1 in 31 July.

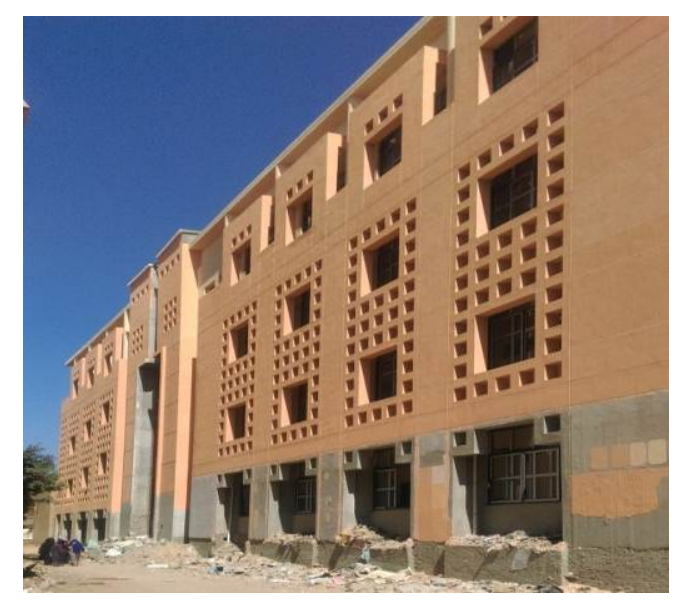

a) Double skin Façade (Faculty of Agriculture)

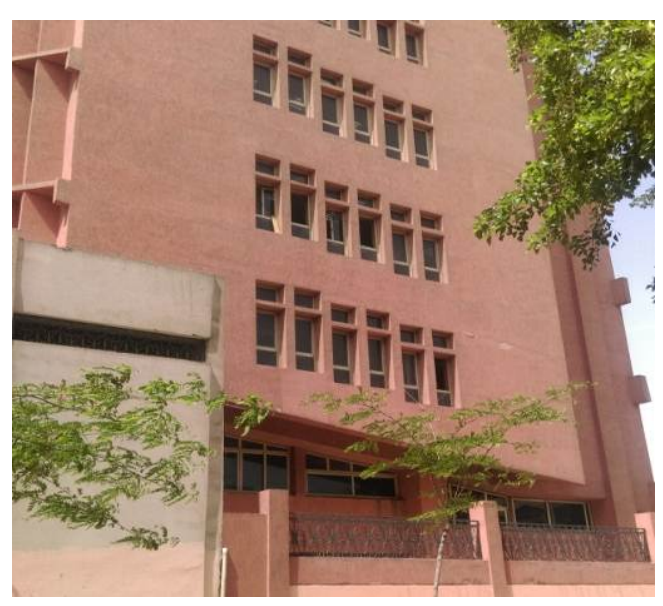

b) Single skin façade (Faculty of Engineering)

Figure 1. External faced of both case studies 


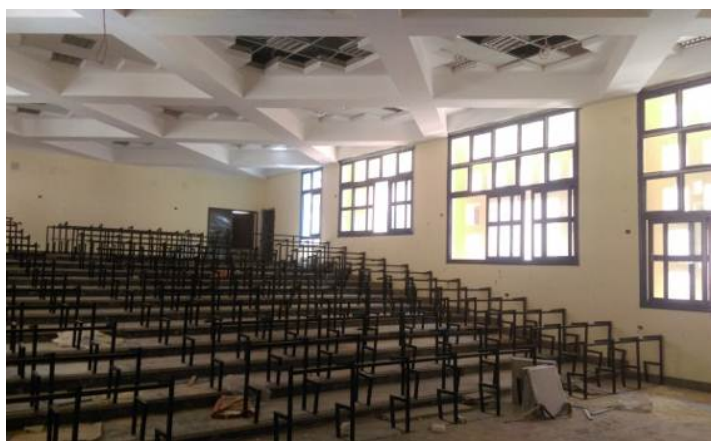

a) Interior veiw of (Faculty of Agriculture)

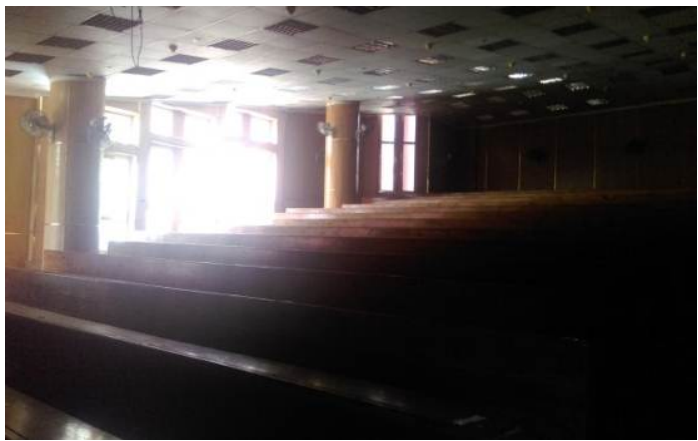

b) Interior veiw of (Faculty of Engineering)

Figure 2. Interior view of both case study halls

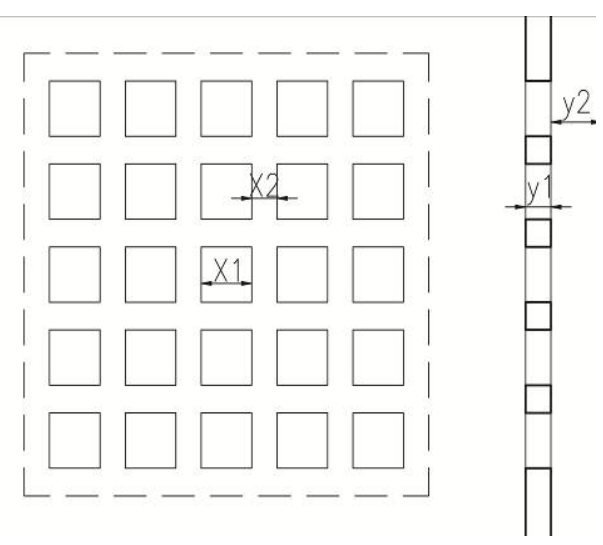
a) Plan
b) Section

Figure 3. Double skin model

In (Figure 3), the double skin façade of faculty of agriculture is configured as grid mashrabyia inspired with horizontal and vertical rows. The main variables are wall depth (WD), and cavity distance between the two walls (CD). The solar protection system used in the building is composed by vertical fixed elements made of concrete slabs and connected to the floors and horizontal elements. These horizontal elements are $0.5 \mathrm{~m}$ distance from the window, configuring a void where air circulates free. Vertical elements have just two contact points with the horizontal structure.

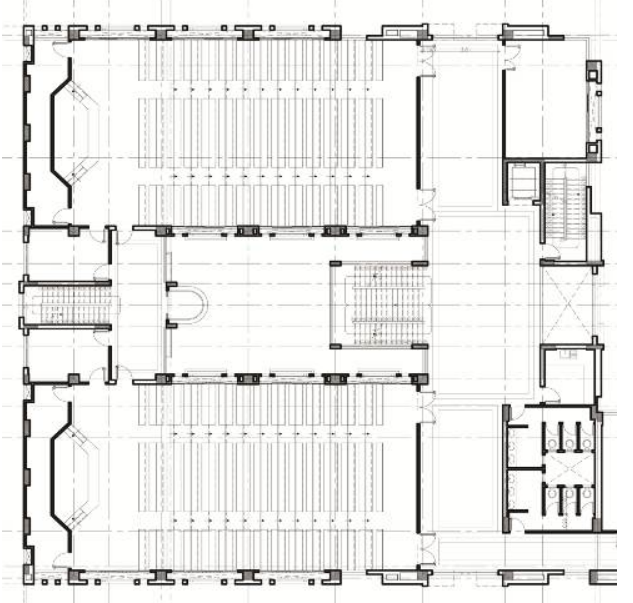

a) Typical Floor plan (Faculty of Agriculture)

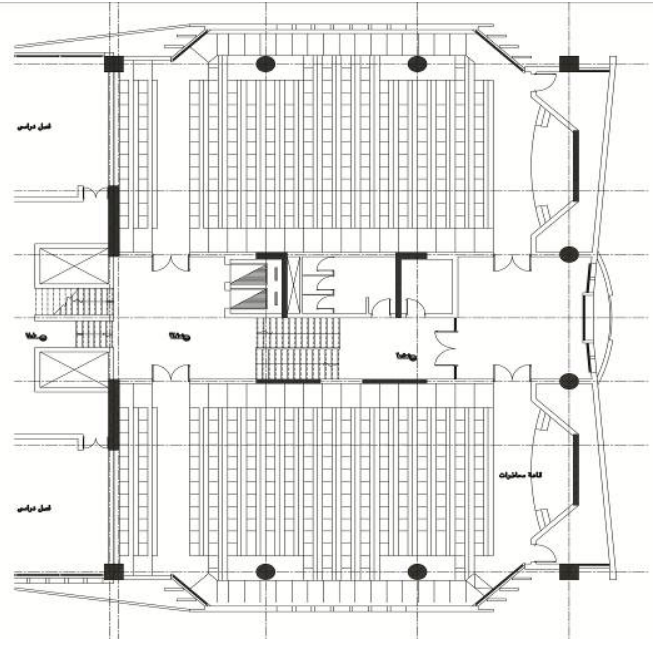

b) Typical Floor Plan (Faculty of Engineering)

Figure 4. Floor plans of both case study halls 


\subsection{Data Collection}

In this study, Lux meter were utilized in order to collect and measure data. It is located in selected locations of the building to record data. Data were collected in three different lecture halls of the two buildings. The collected data can be affected negatively by other side court which is exposed to the direct sunlight through the court; additional light will result to come up with incorrect and unreliable recorded values. Thus, a dark screen is used to close entry of daylight, to create conditions similar to the case of lecture halls of Faculty of Engineering building. Figure (4) explore the difference in floor plans of both lecture halls. Figure (5) describes the location of the lux meter and illustrates the sensor grid image. The recorded data using lux meter in are represented in Table 1,2 and 3.

Daylight is calculated under an overcast sky. A grid measurement system is applied using 2 rows with $2.5 \mathrm{~m}$ intervals and 7 columns of $2 \mathrm{~m}$ spacing from window, accordingly 56 point were traced and measured to represent lighting intensity inside the lecture hall. The height of the sensor grid is set to two levels the first $0.8 \mathrm{~m}$ above the floor that match work plan.

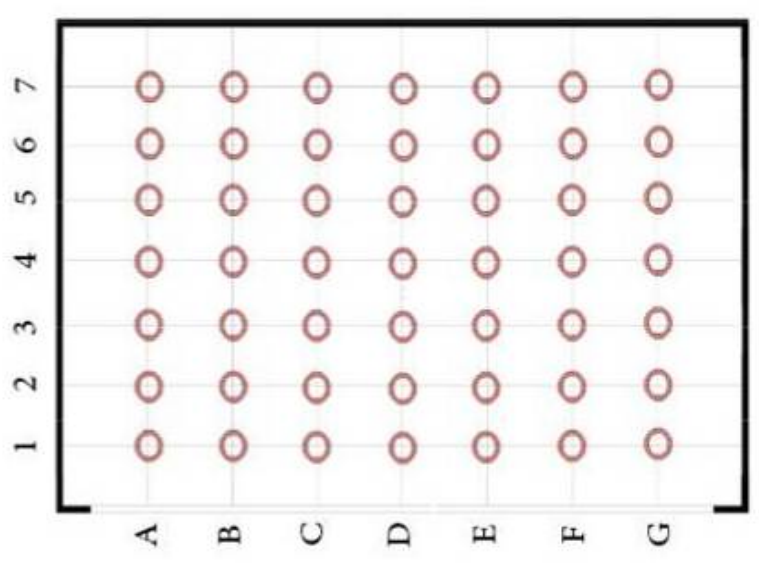

Figure 5. Plan of grid measurement

\subsection{Data Recording}

All data which recorded from south and North Halls were recorded and imported into Golden server software which provides data in both tabular and graphical presentation. Therefore, the overall data recorded at each location could be examined. Day factor method is used to measure daylight intensity inside lecture hall.

Table 1,2,3 presents the relevant recorded daylight distribution presented in single skin façade, double skin façade with 0.15 Thick and 0.3 distances, and double skin façade with 0.35 thick and 0.6 distances; correspondingly. The mean value of recorded values is presented at the end of each table. It is used to compare the three cases, in term of intensity and distribution.

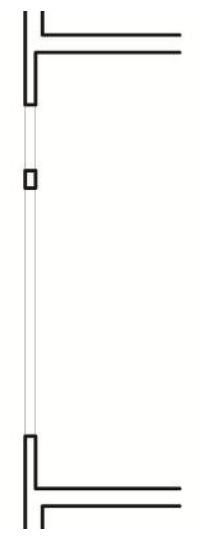

(A) Single Skin

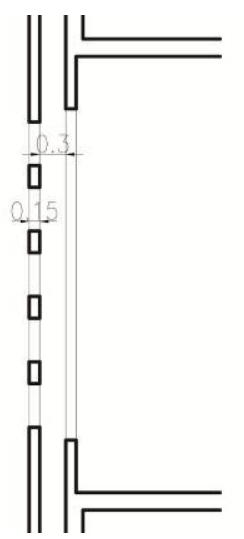

(B) Double skin with 0.15 Thick and 0.3 distances.

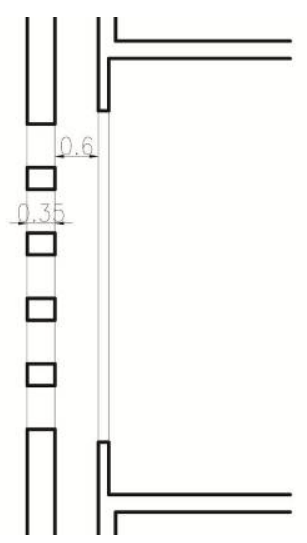

(C) Double Skin with 0.35 thick and 0.6 distances.

Figure 6. A comparison of (average illumination level) for different facade configuration 
Table 1. Lighting intensity in Lux for Single skin Façade

\begin{tabular}{|c|c|c|c|c|c|c|c|}
\hline & 1 & 2 & 3 & 4 & 5 & 6 & 7 \\
\hline $\mathbf{A}$ & 1260 & 570 & 310 & 135 & 81 & 41 & 23 \\
\hline B & 220 & 520 & 172 & 76 & 40 & 30 & 22 \\
\hline C & 1255 & 520 & 172 & 76 & 40 & 30 & 22 \\
\hline D & 240 & 580 & 378 & 139 & 72 & 36 & 18 \\
\hline E & 1252 & 580 & 378 & 139 & 72 & 36 & 18 \\
\hline F & 245 & 520 & 172 & 76 & 40 & 30 & 22 \\
\hline G & 1260 & 570 & 310 & 135 & 81 & 41 & 23 \\
\hline Average & 1260 & 570 & 310 & 135 & 81 & 41 & 23 \\
\hline
\end{tabular}

Table 2. Lighting intensity in Lux for Double skin Façade ( 0.2 wall thickness and 0.25 cavity distance)

\begin{tabular}{cccccccc}
\hline & $\mathbf{1}$ & $\mathbf{2}$ & $\mathbf{3}$ & $\mathbf{4}$ & $\mathbf{5}$ & $\mathbf{6}$ & $\mathbf{7}$ \\
\hline $\mathbf{A}$ & 1090 & 465 & 355 & 205 & 135 & 106 & 75 \\
B & 460 & 312 & 280 & 132 & 58 & 55 & 35 \\
C & 1078 & 430 & 340 & 196 & 129 & 101 & 66 \\
D & 432 & 289 & 280 & 133 & 52 & 56 & 32 \\
E & 1087 & 423 & 346 & 198 & 128 & 102 & 68 \\
F & 450 & 307 & 280 & 138 & 55 & 59 & 38 \\
G & 1100 & 454 & 350 & 204 & 137 & 112 & 72 \\
\hline Average & $\mathbf{1 0 5 0}$ & $\mathbf{4 3 5}$ & $\mathbf{3 6 2}$ & $\mathbf{2 0 1}$ & $\mathbf{1 3 0}$ & $\mathbf{1 0 7}$ & $\mathbf{7 3}$ \\
\hline
\end{tabular}

Table 3. Lighting intensity in Lux for Double skin Façade ( 0.4 wall thickness, and 0.5 cavity distance)

\begin{tabular}{cccccccc}
\hline & $\mathbf{1}$ & $\mathbf{2}$ & $\mathbf{3}$ & $\mathbf{4}$ & $\mathbf{5}$ & $\mathbf{6}$ & $\mathbf{7}$ \\
\hline $\mathbf{A}$ & 920 & 428 & 355 & 312 & 180 & 148 & 140 \\
B & 390 & 312 & 280 & 165 & 110 & 107 & 90 \\
$\mathbf{C}$ & 920 & 403 & 340 & 295 & 172 & 144 & 132 \\
D & 380 & 289 & 280 & 160 & 120 & 95 & 85 \\
E & 989 & 423 & 346 & 306 & 168 & 147 & 135 \\
F & 340 & 307 & 280 & 172 & 135 & 105 & 100 \\
G & 960 & 432 & 350 & 320 & 178 & 152 & 123 \\
\hline Average & $\mathbf{9 4 0}$ & $\mathbf{4 2 1}$ & $\mathbf{3 0 8}$ & $\mathbf{1 7 5}$ & $\mathbf{1 4 8}$ & $\mathbf{1 3 3}$ & $\mathbf{1 0 5}$ \\
\hline
\end{tabular}

\section{Results and Discussion}

Golden surfer version 8 is used to create contour maps that graphically present daylight quantitative and qualitative distribution. These contour maps are used to compare daylight performance of double skin, and single skin facade, and to compare daylight performance of two double skin façades with different physical characteristics as in Figure (7).

The recorded quantitative and qualitative values are measured and compared in term of quantity with the acceptable illumination range of 200 and 300 lux, and compared in term of distribution quality with the acceptable daylight distribution ratios up to 1:10. 


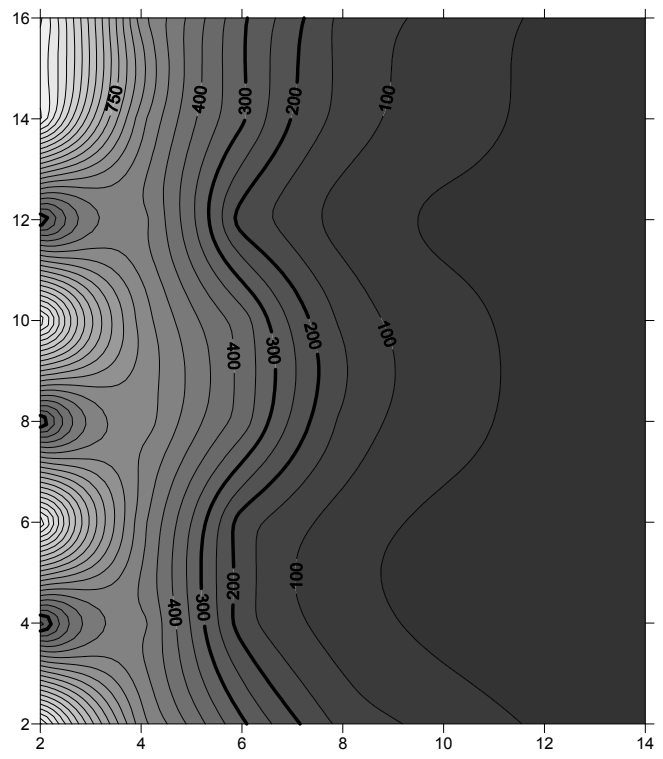

(A) Single Skin.

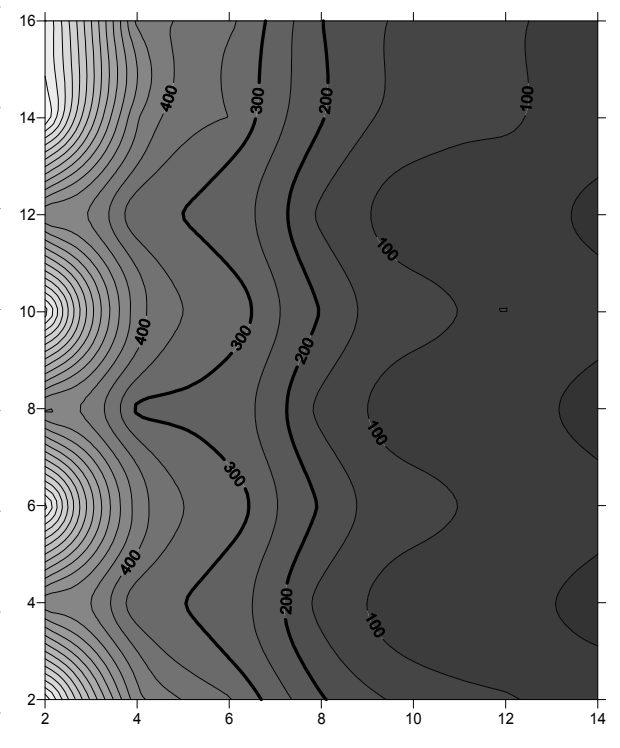

(B) Double skin with 0.15 Thick and 0.3 distances.

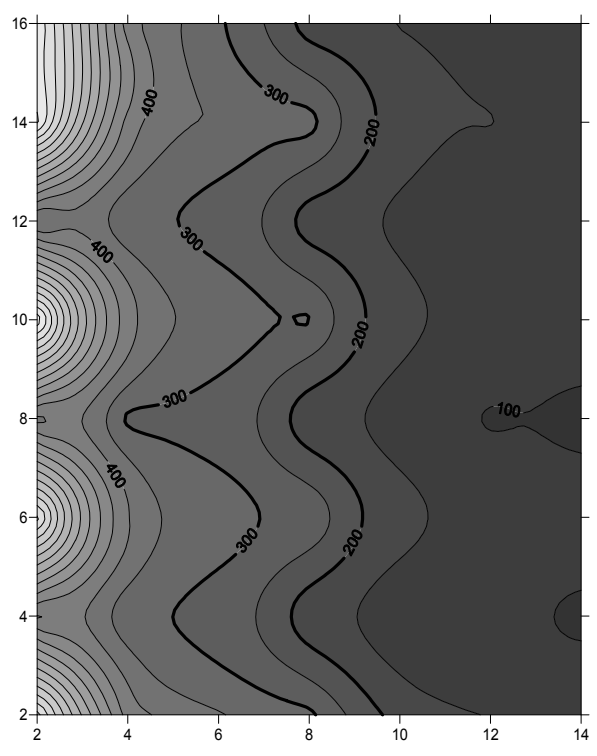

(C) Double Skin with 0.35 thick and 0.6 distances.

Figure 7. Contour maps of recorded illumination level according to golden server

The graphical representation in fig. (7) represents (average daylight intensity) in $\mathrm{Y}$ axis at $\mathrm{x}$ distance from the window in $\mathrm{X}$ axis, three standard deviation curves are traced the first curve (a) represent standard deviation curve of average daylight intensity for single skin façade; the second curve (b) represents standard deviation curve of average daylight intensity for double skin façade with 0.15 Thick and 0.3 distances; and the third curve (C) represents standard deviation curve of average daylight intensity for double skin façade with 0.35 thick and 0.6 distances.

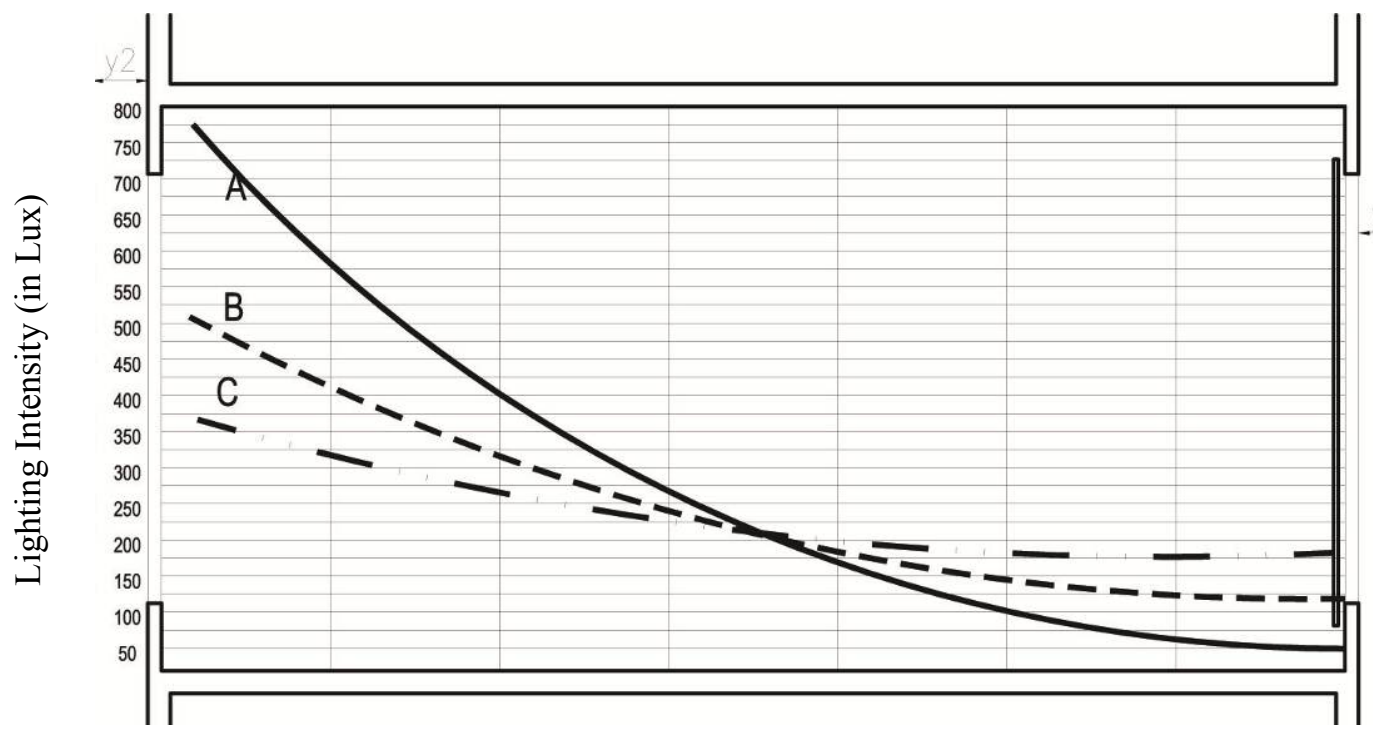

Distance from the window (in meter)

(A) Single Skin
(B) Double skin with 0.15 Thick and 0.3 distances.
(C) Double Skin with 0.35 thick and 0.6 distances.

Figure 8. A comparison of (average illumination level) for different facade configuration 


\subsection{Comparing the Daylight Performance of Double Skin Façade With Single Skin Façade}

Table (4), compares the average daylight performance for single skin façade (a) and double skin façade (c). Figure $(6 \mathrm{a}, 6 \mathrm{c})$ provides a graphical presentation of the results on curves to be easily compared.

Table 4. Evaluated average daylight factor for single and double skin façade (In lux)

\begin{tabular}{lccccccc}
\hline & $\mathbf{1}$ & $\mathbf{2}$ & $\mathbf{3}$ & $\mathbf{4}$ & $\mathbf{5}$ & $\mathbf{6}$ & $\mathbf{7}$ \\
\hline Single wall & 1260 & 570 & 310 & 135 & 81 & 41 & 23 \\
Double Wall (0.4 thick, and 0.5 distance) & 940 & 421 & 308 & 175 & 148 & 133 & 105 \\
\hline
\end{tabular}

In term of intensity, Illumination level of double skin compared to single skin façade reveals that single skin façade records values above standard illumination range of 300 lux for $45 \%$ of space; and records values below lower illumination range of 200 lux for $45 \%$ of space below standard illumination range. Only $10 \%$ of space recorded within the standard illumination range of 200 to 300 lux. On the other hand, double skin illumination record standard illumination range of 200 to 300 lux for $50 \%$ of the space, and $80 \%$ of the space within standard illumination range of 100 to 300 lux.

In term of quality, Illumination distribution of double skin compared to single skin, it reveals that single skin façade is worth range between 0.1 to 10 compared to standard illumination level of 1 to 10 . On the other hand Double skin façade is more efficient in its daylight distribution that ranges between 1 to 7 .

\subsection{Comparing Two Double Skin Façade with Different Wall Thickness and Cavity Distance}

Table (5) compares average daylight level (in lux) for double skin façade at different cavity distance and external skin thickness. The average daylight factor is traced and compared on curves, and further solar exposure has been shown. Figure (6) provides a graphical presentation of the results.

Table 5. Average day lighting factor for two double skin façade the first of ( 0.2 thick, and 0.25 distance), and the other of ( 0.4 thick, and 0.5 distance) (In lux)

\begin{tabular}{lccccccc}
\hline & $\mathbf{1}$ & $\mathbf{2}$ & $\mathbf{3}$ & $\mathbf{4}$ & $\mathbf{5}$ & $\mathbf{6}$ & $\mathbf{7}$ \\
\hline Double Wall (0.2 thick, and 0.25 distance) & 1050 & 435 & 362 & 201 & 130 & 107 & 73 \\
Double Wall (0.4 thick, and 0.5 distance) & 940 & 421 & 308 & 175 & 148 & 133 & 105 \\
\hline
\end{tabular}

In term of intensity, comparing Illumination level of two double skin façade, the first with $0.12 \mathrm{~m}$ thickness and $0.3 \mathrm{~m}$ cavity distance the other with 0.38 thicknesses and $0.6 \mathrm{~m}$ cavity distance declare that the first records values within the standard illumination range of 200 to 300 lux for $30 \%$ of the space; and records values within illumination range of 100 to 3001 ux for $50 \%$ of the space. On the other hand, the second records values within the standard illumination range of 200 to 300 lux for $50 \%$ of space, and records values within illumination range of 100 to 300 lux for $80 \%$ of the space. Accordingly, the larger skin width and cavity distance highly matches standard illumination range.

In term of distribution, Illumination gradual distribution of different two cases reveal that the first ranges between 0.65 to 10 compared to standard illumination level of 1 to 10 . On the other hand the second is more efficient daylight distribution ranges between 1 to 7 . The average range of illumination between the two sides of the halls traced high range and difference in smaller wall width and smaller cavity distance than that of wider wall and large distance wall. This can be explained due to the larger wall width that increases cavity wall efficiency for diffusing and redirecting the skylight into the ceiling and reducing penetrated skylight and direct sunlight. 


\section{Conclusion and Recommendations}

This paper discusses the impacts and benefits of double skin façade on achieving sustainable energy and strategies for management of indoors environment. It evaluates the possible positive effects that the use of double skin facades can have on the indoor environment. According to our results, daylight performance can be achieved by adopting DSF. It offers better delighting in term of quantity and quality than single skin façade.

Illumination intensity in the lecture hall with Single skin façade is highly compared to lecture hall with Double skin facade. Double skin façade reduces illumination intensity compared to single skin façade, at the same time it creates gradual distribution of light and high quality of light. In Single skin façade, illumination range is very high between very bright points near window and very dark points far from window; it is worth range between 1 to 100 compared to range between 1 to 7 of double skin façade. Finally, the physical configuration of double skin façade resulted in a diversity of impacts in term of intensity and distribution. A much more research is still needed in this regard.

The role of double skin façade become clear that it redirect and diffuse a large amount of incoming sunlight by reflection to the ceiling, and diffuse light into the space. It can maximize the redirected natural light and diffuse direct sunlight. At the same time, the external solid wall can shade the glass below to reduce sun penetration into space and beam sunlight into the interior of the space, so it can keep the heat gain to the minimum. Diffuse and reflected light can perform better in reducing the reliance on artificial lighting as well as reduce their equipment, in the other hand it reduce reliance on artificial ventilation and artificial cooling as well as reduce their mechanical equipment. Accordingly, it reduces electricity bills over the years of operating the building.

The research recommends adoption of double skin façade in educational building to face the problems of high illumination level near the window and avoid the high illumination difference and accordingly achieve adaptation in term of daylight quality. The role of double skin façade to introduce natural light in educational buildings is a step to achieve applicable sustainability energy guidelines and strategies for management of educational buildings.

\section{References}

Abdulsalam, M. et al. (2014). Simulation of Day-Lighting Characteristics in the Cavity of Double Glazed Façade. International Journal of Innovative Research in Science, Engineering and Technology, 3(4).

Al-Salal, K. (2006). Improving Day lighting in Tall Buildings in UAE, World Renewable Energy Congress, Florence, Italy, August 19-25.

Boake, T. et al. (2003). understanding the general princibles of the double skin façade system.

Carriere, M., Schoenau, G., \& Besant, R. (1999). Investigation of some large building energy conservation opportunities using the DOE-2 model. Energy Conservation and Management, 40(8), 861-872. https://doi.org/10.1016/S0196-8904(98)00152-6

Cetiner, I., \& Ozkan, E. (2005). An approach for the evaluation of energy and cost efficiency of glass facades. Energy and Buildings, 37, 673-684. https://doi.org/10.1016/j.enbuild.2004.10.007

Cheong, C. et al. (2014). Thermal and Daylighting Performance of Energy-Efficient Windows in Highly Glazed Residential Buildings: Case Study in Korea.

Danny, L., \& Tsang, E. (2008). An analysis of day lighting performance for office buildings in Hong Kong. Elsevier. Volume 43, Pages. 1446-1458.

Elkadi, H., Wiltshire, T., \& Nahyan, S. (1999). Energy management of building envelopes in hot climate, in: Conference Proceedings of Energy \& Environment Development Conference, Port Elizabeth, South Africa.

Fine, I., MacLeod, D., \& Boynton, G. (2003). Surface segmentation based on the luminance and color statistics of natural scenes. J. Opt. Soc. Am, A/, 20. https://doi.org/10.1364/josaa.20.001283

Fontoynont, M. (2004) "SynthLight Handbook Chapter 2: Daylighting" https://www.new-learn.info/packages/synthlight/handbook/doc/chapter2.

Gunawan, B., Juwana, J., Priatman, J., Sujatmiko, W., \& Sulistiyanto, T. (2012). Energy Efficiency Guidelines for Building Design in Indonesia 2 Technical Design Guide (1st ed.). Energy Efficiency and Conservation Clearing House Indonesia.

Hamza, N., \& Underwood, C. (2005). CFD assisted modeling of double skin facades in hot arid areas, in: Proceedings of 9th International Building Performance Simulation Association Conference (IPBSA), Montreal, Canada, August 15-18. 
Hamza, N., Dudek, S., \& Elkadi, H. (2001a). Thermal performance of double skin facades in hot arid areas, in: ICBEST 2001, Ottawa, Canada, July 23-27.

Hamza, N., Dudek, S., \& Elkadi, H. (2001b). Impacts of changing facade configurations on office building energy consumption in hot arid climates, in: CLIMA 2000, Napoli, Italy, September 15-18, (CD-ROM).

Hamza, N., Gomaa, A., \& Underwood, C. (2007). Day lighting and thermal analysis of an obstructed double skin façade in hot arid areas. Northumbria University, Newcastle Upon Tyne, UK.

Hopkinson, R. G., Petherbridge, P., \& Longmore, J. (1966). Daylighting. Heinemann, London.

IES North America. (2000). IESNA. 9th Handbook. 9th ed. Illumination Engineering Society of North America.

Kensek, K., \& Suk, J. (2011). Daylight Factor (overcast sky) versus Daylight Availability (clear sky) in Computer-based Day lighting Simulations. Journal of Creative Sustainable Architecture \& Built Environment.

Madjidi, M. (2006). A Physical simulation model for prediction of temperature and air flow in double skin facades, in: Proceedings of the 7th Conference on System Simulation in Buildings, Leige, France, December 11-13.

Napier J. (2015). Climate based Façade Design for busniss buildings with examples from central London. published in Building Journal. https://doi.org/10.3390/buildings5010016

Oesterle, E., Lieb, R., Lutz, M., \& Heusler, W. (2001). Double Skin Facades, Integrated Planning, Prestel.

Ozbalta, T., \& Kartal, S. (2010). Heat gain through Trombe wall using solar energy in a cold region of Turkey. Academic Journals, 5(18), 2768-2778.

Pedrini, A., Westphal, F., \& Lamberts, R. (2002). A methodology for building energy modeling and calibration in $\begin{array}{llll}\text { warm climates. Building and } & \text { Environment, }\end{array}$ https://doi.org/10.1016/S0360-1323(02)00051-3

Rahmani et al. (2012). How Double Skin Façade's Air-Gap Sizes Effect on Lowering Solar Heat Gain in Tropical Climate? World Applied Sciences Journal, 18(6), 774-778.

Sadineni, S., Madala, S., \& Boehm, R. (2011). Passive building energy savings: A review of building envelope components. Elsevier, 15, pp. 3617-3631. https://doi.org/10.1016/j.rser.2011.07.014

Schneider, M. (2002). Do School Facilities Affect Academic Outcomes? National Clearinghouse for Educational Facilities.

Ullah, I. (2014). Daylight for Healthy Indoor Environment and Energy Benefits. International Journal of Ophthalmology \& Eye Science (IJOES).

Y1lmaz, Z., \& Cetintas, F. (2005). Double skin facade's effects on heat losses of office buildings in Istanbul. Elsevier Energy and Buildings, 37, 691-697. https://doi.org/10.1016/j.enbuild.2004.07.010

\section{Note}

Note 1. Points of view deduced based on an interview with lecturers. The interveiw aims to evaluate their assessment of the impacts of window size and distribution on environmental conditions in term of heating, daylight, and ventilation.

\section{Copyrights}

Copyright for this article is retained by the author(s), with first publication rights granted to the journal.

This is an open-access article distributed under the terms and conditions of the Creative Commons Attribution license (http://creativecommons.org/licenses/by/4.0/). 